\title{
Rising China and Global Investment Governance: An Overview of Prospects and Challenges
}

\author{
Dilini Pathirana \\ Lecturer (Probationary), Faculty of Law, University of Colombo, Sri Lanka \\ dilinipathirana@ymail.com
}

\begin{abstract}
International investment is one of the fields of global governance that is likely to be affected by China's rise as a global superpower in general, and its rise as a global investor in particular. It has become manifest by China's leadership in forming of the G2o Guiding Principles for Global Investment Policymaking and in establishing the Asian Infrastructure Investment Bank, while signaling the country's growing capacity to influence global investment governance. However, China's aspiration to steer global investment governance is being hindered by the increased backlash against globalisation and the investment treaty regime, as well as the rapid growth of Chinese investments. At the same time that protectionist measures aimed at Chinese investments are on the rise, the Belt and Road Initiative is underway, which will increase Chinese desire to safeguard the interests of Chinese investors. Consequently, it is possible that a Beijing-based pole in global investment governance could emerge, just as reforms are underway to address the legitimacy crisis in the regime.
\end{abstract}

\section{Keywords}

China - global governance - investment treaty regime - global investment governance 


\section{Introduction}

Recent decades have been marked by China's economic, military and diplomatic rise. ${ }^{1}$ Indeed, the notion of "rising China" has been expounded as the most influential phenomenon affecting the world order in the 21st century. ${ }^{2}$ China's rise has had a profound effect on the world's contemporary geopolitical landscape, and has been accompanied by the emergence of a new international order which, together with the rise of the BRICS - the economic alliance encompassing Brazil, the Russian Federation, India, China and South Africa, is collectively referred to as the "rise of the rest". ${ }^{3}$ This new world order is marked by intensified geoeconomic competition in relation to economic tools that play a key role in sustaining the current international order, with the USA and its Western allies traditionally having been at the forefront of global governance. ${ }^{4}$ However, China has been utilizing the economic tools at her disposal, such as trade, investment and finance in order to project power abroad and advance China's geopolitical objectives. ${ }^{5}$ This paper focusses on

1 See generally Jane Golley and Ligang Song, eds., Rising China: Global Challenges and Opportunities (Canberra, CAN: ANU E Press, 2011); Ronald Huisken, ed., Rising China: Power and Reassurance (Canberra, CAN: ANU E Press, 2009); G. John Ikenberry, "The Rise of China and the Future of the West: Can the Liberal System Survive?," Foreign Affairs, February 2008, https://www.foreignaffairs.com/articles/asia/2008-01-01/rise-china-and-future-west.

2 See generally Zheng Yongnian and Lim Wen Xin, "The Changing Geopolitical Landscape, China and the World Order in the 21st Century," China: An International Journal 15, no. 1 (2017).

3 See generally Anthea Roberts, Is International Law International? (Oxford, UK; New York, NY: Oxford University Press, 2017): Jan Wouters, ed., China, the European Union and Global Governance, Leuven Global Governance (Cheltenham, UK; Northampton, MA, USA: Edward Elgar, 2012); Zheng Yongnian and Lim Wen Xin, "The Changing Geopolitical Landscape, China and the World Order in the 21st Century." For a detailed discussion on the rise of countries such as China, India and Brazil in the current global order, while giving rise to a transition from unipolarity to multipolarity see Randall Schweller, "Emerging Powers in an Age of Disorder," Global Governance-Emerging Powers and Multilateralism in the Twenty-First Century) 17, no. 3 (2011).

4 Mark Beeson, "Geopolitics versus Geoeconomics: The New International Order," The conversation, March 14, 2015, https://theconversation.com/geopolitics-versus-geoeconomics-the -new-international-order-38824. See further Michael Du, "China's 'One Belt, One Road' Initiative: Context, Focus, Institutions, and Implications," The Chinese Journal of Global Governance, no. 2 (2016): 33 .

5 See generally "Geo-Economics with Chinese Characteristics: How China's Economic Might Is Reshaping World Politics," (The World Economic Forum, January 2016), www3.weforum.org/ docs/WEF_Geoeconomics_with_Chinese_Characteristics.pdf. See further Nicholas Kitchen, ed., "China's Geoeconomic Strategy: Executive Summary," LSE IDEAS (London, UK: London School of Economics and Political Science, June 2012). 
international investment - a field with which China has increasing engagement and is entrenching its position as one the world's leading capital-importer and capital-exporter. ${ }^{6}$

Parallel to expanding China's profile in the field of foreign investment, it concluded a web of international investment agreements (IIAS), which include 130 bilateral investment treaties (BITS) as well as 21 other agreements with investment provisions. ${ }^{7}$ This decade has seen China become ever-more engaged in the investor-state dispute settlement (ISDS) regime, either as a host or home state. ${ }^{8}$ China's presidency in the G2o has particularly demonstrated its leadership in forming the G2o Trade and Investment Working Group in 2016. ${ }^{9}$ This Working Group aimed towards the adoption of the G2o Guiding Principles for Global Investment Policymaking, which has been admired as a successful attempt to "outline the architecture of a comprehensive framework on international investment."10 Furthering its effort to facilitate foreign investment, in 2017, China joined up with the group of States which is currently working on developing a multilateral framework on investment facilitation under the auspices of the World Trade Organisation (WTO).. ${ }^{11}$ Consequently, international investment is one of the fields of global governance that is likely to be affected

6 See for example unctad, ed., Investment and the Digital Economy, World Investment Report 2017 (New York and Geneva: United Nations, 2017).

7 UNCTAD, “International Investment Agreements Navigator," Investment Policy Hub, April 2018, http://investmentpolicyhub.unctad.org/IIA/CountryBits/42\#iiaInnerMenu.

8 Dilini Pathirana, "A Look into China's Slowly Increasing Appearance in ISDS Cases," Investment Treaty News 8, no. 3 (2017): 5-7. See further Leon E Trakman, "China and Investor-State Arbitration,” UNSw Law Research Paper, no 2012-48, October 2012.

9 For a discussion on China and G-2o see Mingjiang Li, "Rising from Within: China's Search for a Multilateral World and Its Implications for Sino-US Relations," Global Governance 17, no. 3 (2011): 331-51. See further Hongying Wang, "Toward A Global Investment Governance Framework:An Opportunity for the ChinesePresidency of the G20," Centre for International Governance Innovations, November 5, 2015, https://www.cigionline.org/publications/ toward-global-investment-governance-framework-opportunity-chinese-presidency-g20.

10 Karl Sauvant, "China Moves the G2o toward an International Investment Framework and Investment Facilitation," in Julien Chaisse, ed., China's Three-Prong Investment Strategy: Bilateral, Regional and Global Tracks (London: Oxford University Press, 2018). See further Karl Sauvant, "China, the G2o and the International Investment Regime in Andrea Goldstein and Alessia Amighini, eds., Towards the 2016 G20: Global Analyses and Challenges for the Chinese Presidency, special issue of China and the World Economy, 24, no. 4 (2016): 73, SsRN: https://ssrn.com/abstract $=2789827$.

11 "Joint Ministerial Statement on Investment Facilitation for Development" (World Trade Organisation, December 2017), https://www.wto.org/english/news_e/news17_e/minis_13dec 17_e.htm. See further Axel Berger, "What's next for the investment facilitation agenda?," Columbia FDI Perspectives-Perspectives on Topical Foreign Direct Investment Issues, no. 224 (April 2018), http://ccsi.columbia.edu/publications/columbia-fdi-perspectives/. 
by China's rise as a global superpower in general, and its rise as a global investor in particular. Against this background, the paper intends to assess the effect of China's emerging role in the field of foreign investment on global investment governance, which is highly fragmented and under fire. In doing so, the paper discusses whether or not China's rise will help to sustain the current international system for the protection of foreign investment, or will seek to replace it with a China-led approach. It further identifies the challenges that China will face if she persists with the current mechanisms employed to protect the private interests of foreign investors, while discussing the effect of China's Belt and Road Initiative (BRI) on the cohesion of global investment governance which is currently at a stake.

\section{Theoretical Framework: The Notion of Global Governance}

This paper expects to assess the effect of China's rise on international investment governance. Thus the notion of global governance should be initially elucidated as the former comes under the broad framework of the latter. ${ }^{12}$ The term governance, in general, connotes an activity or doing something. ${ }^{13}$ If an activity must be institutionalized, then there should be an institution which eventually becomes the means of governance or actor of governance. ${ }^{14}$ It has been thus argued that governance should be differentiated from government, particularly in the context of current international order, which lacks hierarchy and is absent a government. ${ }^{15}$ Nevertheless, several "government-like" events occur in the international arena in the absence of a global government, aimed at solving global problems, providing global public goods, managing global commons, and protecting widely-accepted fundamental values. Accordingly, three main features of global governance have been expounded

12 For a detailed discussion on global governance see José Antonio Alonso, ed., Global Governance and Rules for the Post-2015 Era: Addressing Emerging Issues in the Global Environment, The United Nations Series on Development (London, LON: Bloomsbury Academic, 2015); Yu Keping, "Governance and Good Governance: A New Framework for Political Analysis," Fudan Journal of the Humanities and Social Sciences 11, no. 1 (March 2018): 1-8, https://doi .org/10.1007/s40647-017-0197-4.

13 Lawrence Finkelstein, "What Is Global Governance?" Global Governance 1, no. 3 (1995): 367 .

14 Finkelstein, "What Is Global Governance?".

15 Hongying Wang and James N. Rosenau, "China and Global Governance," Asian Perspective 33, no. 3 (2009): 5; Ann Florini, "Global Governance and What It Means," The Brookings Institution, February, 2009, https://www.brookings.edu/on-the-record/global-gover nance-and-what-it-means/; Keping, "Governance and Good Governance". 
in the literature with respect to the western ideology of global governance. Firstly, it emphasises the global scale of many of contemporary issues in the world. ${ }^{16}$ Secondly, it demonstrates the increased role of non-state entities in shaping how world is governed by making demands, framing goals, issuing directives, and pursuing goals. ${ }^{17}$ Thirdly, it presumes the validity of a number of western-originated norms such as market competition, human rights, democracy, transparency, accountability, and rule of law. ${ }^{18}$

The notion of global governance is buttressed by other concepts such as multilateralism and universalism. Multilateralism involves several States acting together or coordinating policies through formal or informal institutions to provide global solutions for global problems, providing global public goods and etc. ${ }^{19}$ The parameters of multilateralism have been expanded beyond States and inter-state relations or intergovernmental organizations and regimes, and into global governance institutions which involve a range of nongovernmental and societal forces transforming the international order. ${ }^{20} \mathrm{In}$ this context, multilateralism is vital for global governance as a method which "describes a problem-solving strategy or organizing principle" by providing choice to "include, involve, and gain the agreement of as many states as possible to solve global problems or produce global benefits."21 This inclination towards multilateralism is manifested in institutions such as the United Nations (UN) and the WTO, which provide the international community with inclusive fora for debates that require global or multilateral commitments. Multilateralism therefore encourages "broader and more inclusive solutions", 22 and global solutions for global problems, achieved by cooperation amongst States, intergovernmental organisations, and non-governmental organisations. Likewise, the Universalist camp believes in an "an interconnected one world, one law-based international order", and considers multilateral treaties and the international organizations associated with them as a way to achieve

16 Wang and Rosenau, "China and Global Governance," 6.

17 Wang and Rosenau.

18 Wang and Rosenau.

19 Fen Osler Hampson and Paul Heinbecker, "The 'New' Multilateralism of the TwentyFirst Century," Global Governance 17, no. 3 (2011): 299: See further on Multilateralism Jose Alvarze, "Multilateralism and Its Discontents," European Journal of International Law 11, no. 2 (2000): 393; Harlan G. Cohen, "Multilateralism's Life-Cycle," American Journal of International Law 112 (forthcoming 2018). For a detailed discussion on China's views and its policy towards international multilateralism see Li, "Rising from within." James Muldoon, "Return to Multilateralism (1992-)," in Cathal Nolan, ed., Oxford Bibliographies in International Relations (New York, NY: Oxford University Press, 2012).

21 Cohen, "Multilateralism's Life-Cycle."

22 Cohen. 
a "more enlightened international society", "community," "global village," "neighborhood," or a "family of nations."23 In this context, multilateral treaties and international organisations are of vital significance to promote an international rule of law and to serve as the building blocks of an international constitution, while providing the way to solve global problems effectively and efficiently. ${ }^{24}$ It is thus apparent that Universalists' believe in multilateralism as the ideal strategy for regulating international behavior, and their confidence in the multilateral approach to establish a "more enlightened international society"25 buttresses the notion of global governance through supporting the multilateralism upon which the notion of global governance is premised.

Parallel to China's increased integration into the post-World War II international order, a discourse on global governance was developed in the Chinese context focusing on China's role in global affairs. ${ }^{26}$ This discourse resulted in the articulation of a notion of global governance with Chinese characteristics. ${ }^{27}$ The Chinese idea of global governance is premised on the theme of a "harmonious world", and contains four main principles which advocate reformation of the existing international order. ${ }^{28}$ The first principle is the 'democratization of international relations', emphasizing the equitable participation of states in international affairs and a broad consultancy with respect to common international problems. ${ }^{29}$ The second principle is 'justice and common prosperity', urging that all countries should have the opportunity to benefit from economic globalization and emphasising the significance of South-South cooperation amongst developing countries. ${ }^{30}$ The third principle is 'diversity and tolerance', focusing on giving due recognition to the plurality and diversity of civilizations which are marked by different histories, cultures,

23 Gabriella Blum, "Bilateralism, Multilateralism, and the Architecture of International Law," Harvard International Law Journal 49, no. 2 (2008): 323.

24 Blum, "Bilateralism, Multilateralism, and the Architecture of International Law."

25 Blum.

26 Chen Zheng, "China's Domestic Debate on Global Governance-What Do Chinese Scholars and Policymakers Envision for Beijing's Role in the International Order?," The Diplomat, November, 2016, https://thediplomat.com/2016/11/chinas-domestic-debate -on-global-governance/. For a critical assessment of rising China's role in global affairs see Stewart Patrick and Farah Thaler, "China, the United States, and Global Governance: Shifting Foundations of World Order," International Institutions and Global Governance Programme, (Beijing, China, 2010), www.cfr.org/content/thinktank/CFR_CICIR_Meeting Note.pdf.

27 For a detailed discussion on Chinese views on the concept of global governance see Wang and Rosenau, "China and Global Governance."

28 Wang and Rosenau.

29 Wang and Rosenau.

3o Wang and Rosenau. 
economic models and political systems in a manner which ensures an equal opportunity for growth. ${ }^{31}$ The fourth principle is 'the peaceful resolution of international conflicts', which urges tackling common problems based on mutual trust and cooperation instead of dealing with them individually or by using force. ${ }^{32}$

It is thus apparent that the Chinese view on global governance goes beyond the emphasis on multilateral approach to solve global problems and to provide global goods. China's broad perception of the notion of global governance must have been certainly encouraged by the shared dismay of the Global South about the contemporary international order, driven as it is by western ideology, and multilateralism provides hegemonic powers with enhanced space to dictate rules on global governance. ${ }^{33}$ This is made obvious by the first principle of the Chinese ideology on global governance: the "democratization of international relations." It aims to change the western-driven international order, the credibility of which has been disputed, with more room particularly for the Global South to discuss and make decisions on global issues. Such considerations must have undoubtedly encouraged China to articulate its ideology emphasising elements such as ensuring equitable participation of States in international affairs, South-South cooperation amongst developing countries, and providing equal opportunity for the growth of different civilizations. Nevertheless, the Chinese ideology of global governance is based on the outlook of "harmonious world" demonstrating its inclination towards the global multilateralism, ${ }^{34}$ and thus shares the fundamental perception upon which the western notion of global governance is premised. Moreover, the Chinese ideology articulates the phenomenon of economic globalisation by stressing the need for all countries to have more opportunities to benefit from the process. This articulation makes it clear that despite certain ideological rifts between the western and Chinese notions of global governance, international economic governance is at the core of global governance discourse as the world economy matters to all States due to their increased integration and interdependence of national economies owing to increased economic globalization.

$31 \quad$ Wang and Rosenau.

32 Wang and Rosenau.

33 See generally Li, "Rising from within."

34 For a concise discussion on the notion of harmonious world see Li, "Rising from within"; Wang and Rosenau, "China and Global Governance." 


\section{International Investment Governance: An Overview of Status Quo}

International economic governance is a key feature of global governance. ${ }^{35}$ The former has been expounded as a "set of norms and institutions along which rules are generated to manage the global economy". ${ }^{6}$ States, intergovernmental organizations and non-governmental organizations play an important role in international economic governance, with businesses being the main actors. ${ }^{37}$ Foreign investment constitutes one of the main pillars of the global economy, and thus international investment governance undoubtedly represents one of the main aspects of international economic governance. Foreign investment is particularly significant to the global economy as it drives economic globalisation, while making available the required capital to construct global value chains and facilitating the trade that allows goods and services to reach the regions where they are in demand. ${ }^{38}$ It is thus apparent that international investment is inherently entwined with international trade, the combination of which drives global economic growth and development. However, the existing international order lacks any multilateral arrangement under which matters relating to international trade and investment are jointly regulated. Therefore, their governance at the international level developed separately, except a few exceptions such as trade-related investment measures. The origin of this separation was marked by the futile attempt taken to adopt the Havana Charter in 1947 and to establish the International Trade Organisation (ITO), in relation to which negotiations further laid bare the lack of consensus on three basic provisions of investment protection: national

35 For a detailed and critical assessment of the current international economic governance see Daniel Drezner, "The Irony of Global Economic Governance-The System Worked," International Institutions and Global Governance Programme Working Paper, October 2012, www.cfr.org/content/publications/attachments/IIGG_WorkingPaper.pdf; See further Paola Subacchi and Stephen Pickford, "International Economic Governance: Last Chance for the G2o?," Chatham House The Royal Institution of International Affairs, November 2015, https://www.chathamhouse.org/publication/international-economic -governance-last-chance-g20; Marco Buti, "The New Global Economic Governance: Can Europe Help Win the Peace?" Robert Triffin International Conference, (Brussels, Belgium, June 2017), ec.europa.eu/info/sites/info/files/economy-finance/marco-buti-the -new-global-economic-governance.pdf; Didier Jacobs, "Democratizing Global Economic Governance," Conference on Alternatives to Neoliberalism, (May 2002), www.new-rules .org/storage/documents/afterneolib/jacobs.pdf.

36 Jacobs, "Democratizing Global Economic Governance," 1.

37 Jacobs.

38 See generally oecD, "How International Investment is Shaping the Global EconomySocial, Economic, and Policy Perspectives" oECD Week 2015, www.oecd.org/daf/ inv/2015-international-investment-blog-compilation.pdf. 
treatment (NT), most-favoured-nation (MFN) treatment and just compensation for expropriation. ${ }^{39}$ Since then, concluding a multilateral legal framework on promotion and protection of foreign investment has proved impossible mainly due to the inability of States to agree on the scope and content of standards of protection that should be accorded to foreign investors. ${ }^{40}$ As a result, international investment governance is neither directed by a multilateral legal agreement which articulates global rules on investment-related matters nor driven by a specific multilateral institution. Thus, the promotion, protection, and liberalisation of foreign investments has occurred through bilateral regulation, and by concluding Bilateral Investment Treaties (BITs) and Free Trade Agreement (FTAs) which include provisions on cross-border investments. These BIT S and FTAs have given rise to a web of treaties that are commonly referred to as International Investment Agreements (IIAs), over 3000 of which have been concluded thus far, with a few leading mega-regional treaties expected in near future such as the Comprehensive and Progressive Agreement for Trans-Pacific Partnership (С PTPP), Transatlantic Trade and Investment Partnership (TTIP) and Regional Comprehensive Economic Partnership (RCEP). The amount of IIAs per se demonstrates the decentralised nature of international investment governance, while giving rise to the fragmentation of international investment governance. ${ }^{41}$ Internal coherence and predictability of the jurisprudence has been hampered by the inconsistent rulings on treatment standards accorded to foreign investors by utilizing the Investor-State Dispute Settlement (ISDS) mechanism. ${ }^{42}$ The lack of central authority to oversee decisions rendered

39 See for example Andrew Newcombe and Lluís Paradell, Law and Practice of Investment Treaties: Standards of Treatment (Austin; Boston; Chicago; New York; The Netherlands: Kluwer Law International, 2009); Jonathan Bonnitcha, Lauge Poulsen, and Michael Waibel, The Political Economy of the Investment Treaty Regime (New York, NY: Oxford University Press, 2017).

For a detailed discussion on previous attempts taken to conclude a multilateral investment agreement see Newcombe and Paradell, Law and Practice of Investment Treaties.

41 For a detailed discussion on the investment treaty regime which has recently come to suffer from fragmentation, inconsistency, incoherence and unpredictability see UNCTD, "Towards a New Generation of International Investment Policies: UnCTAD's Fresh Approach to Multilateral Investment Policy-Making", Issue Note 5, July 2013, unctad.org/ en/PublicationsLibrary/webdiaepcb2013d6_en.pdf. For a detailed discussion on critical issues that affect the international investment regime see Karl Sauvant and Federico Ortino, "Improving the International Investment Law and Policy Regime: Options for the Future," Ministry for Foreign Affairs of Finland, ccsi.columbia.edu/files/2014/o3/ Improving-The-International-Investment-Law-and-Policy-Regime-Options-for-the -Future-Sept-2013.pdf.

42 David Collins, An Introduction to International Investment Law (New York, NY: Cambridge University Press, 2017). 
by such ad hoc arbitration tribunals and the non-applicability of the doctrine of precedent have further contributed to the fragmented nature of the jurisprudence on international investment. ${ }^{43}$

Nevertheless, IIAs which afford substantive and procedural protections to foreign investors form the foundation of the "investment treaty regime" which consist of "investment treaties; the set of treaties, rules, and institutions governing investment treaty arbitration; and the decisions of arbitral tribunals applying and interpreting investment treaties." ${ }^{\text {4 }}$ IIAs conventionally include a set of common standards of protections, including NT, MFN treatment, Fair and Equitable Treatment (FET), full protection and security (FPS), and protection against uncompensated nationalisation and expropriation. Foreign investors are further vested with the right to challenge alleged infringements of these standards by engaging the ISDS mechanism embedded in the IIAS themselves. The ISDS mechanism thus provided foreign investors with a "transnational" form of dispute settlement mechanism by allowing them to directly and unilaterally initiate an internationally binding arbitration against host States whose conduct or measures have allegedly negatively impacted foreign investments and, thereby violated the substantive treaty protection accorded to them by relevant investment treaties. ${ }^{45}$ The ISDS mechanism ousted the classic inter-state nature of investment protection which allowed only home States to pursue an action on behalf of aggrieved foreign investors. It further resulted in establishing the control of foreign investors over the system of protecting foreign investment through investment treaties by providing them with a delocalised and depoliticised dispute resolution mechanism. However, IIAs have been conventionally drafted without assigning responsibilities to the foreign investors who ultimately benefit from the treaties. ${ }^{46}$ This omission is a commonly identified reason for the imbalance of international system for the protection of foreign investment through treaties, which is criticised for being

43 Collins, An Introduction to International Investment Law; Bonnitcha, Poulsen, and Waibel, The Political Economy of the Investment Treaty Regime, 28.

44 Bonnitcha, Poulsen, and Waibel, The Political Economy of the Investment Treaty Regime, 3.

45 José Alvarez and Hague Academy of International Law, The Public International Law Regime Governing International Investment (Leiden; Boston: Martinus Nijhoff Publishers, 2011), 55-6. For a detailed discussion on ISDS mechanism see UNCTD, Investor-State Dispute Settlement UNCTAD Series on Issues in International Investment Agreements II (Geneva: United Nations, 2014). For criticisms of the ISDS mechanism, see generally M Michael Waibel et al., eds., The Backlash against Investment Arbitration: Perceptions and Reality (Alphen aan den Rijn: Kluwer Law International 2010).

46 Bonnitcha, Poulsen, and Waibel, The Political Economy of the Investment Treaty Regime, 11, $14-5$. 
biased towards the protection of private interests of foreign investors to the detriment of the public interest of host States. ${ }^{47}$

At the same time, the difficulty of States to demarcate the content and scope of substantive treaty protections resulted in vaguely drafted and ill-defined standards of protection which provided arbitral tribunals with an enhanced interpretative discretion to decide the content and scope of the protection that foreign investors enjoy under a given treaty. This interpretative discretion was executed by private arbitrators who culturally aligned with the private interests of foreign investors, rather than public interests of host States and their publicoriented policies. This cultural favoritism, alongside the professional bias of arbitrators resulted in a trend towards the expansive treaty interpretation particularly in respect of two frequently invoked standards of protection, i.e. the prohibition against uncompensated expropriation and the FET standard. ${ }^{48}$ This trend resulted in excessively protecting the interests of foreign investors at the expense of the host States' right to regulate in the public interest. ${ }^{49}$ This scenario provoked concerns over the international system for the protection of foreign investment through treaties, which mainly query the desirability of reviewing host States' measures or conducts by private arbitrators who are appointed on an ad hoc basis and, its impact on the social fabric and national economy of a given host State which was found liable for violating substantive treaty protections accorded to foreign investors. ${ }^{50}$

Therefore, the existing international legal framework on foreign investment has been subjected to defiance by various parties, particularly including Statesone of the main actors in the field of foreign investment. A number of States

47 See for example Collins, An Introduction to International Investment Law.

48 See for example Muthucumaraswamy Sornarajah, "The Neo-Liberal Agenda in Investment Arbitration: Its Rise, Retreat and Impact on State Sovereignty" in Wenhua Shan, Penelope Simons and Dalvinder Singh, eds., Redefining Sovereignty in International Economic Law (Oxford and Portland, Oregon: Hart 2008); Joachim Karl, "International Investment Arbitration: A Threat to State Sovereignty?" in Wenhua Shan, Penelope Simons and Dalvinder Singh, eds., Redefining Sovereignty in International Economic Law (Oxford and Portland, Oregon: Hart 2008); Nicolas Hachez and Jan Wouters, "International Investment Dispute Settlement in the Twenty-First Century: Does the Preservation of the Public Interest Require an Alternative to the Arbitral Model?" in Freya Baetens, ed., Investment Law within International Law: Integrationist Perspectives (Cambridge: Cambridge University Press 2013); Surya Subedi, International Investment Law: Reconciling Policy and Principle (Oxford and Portland, Oregon: Hart 2008).

49 See for example Gus Van Harten et al, "Osgood Hall Public Statement on the International Investment Regime,” York University, August 2010, https://www.osgoode.yorku.ca/ public-statement-international-investment-regime-31-august-2010/.

$5^{\circ}$ See generally Freya Baetens, ed., Investment Law within International Law: Integrationist Perspectives, (Cambridge: Cambridge University Press 2013). 
have already rejected the existing system of protecting foreign investment through investment treaties, which is implemented by the ISDs mechanism. ${ }^{51}$ In response, some of the States devised newer versions of investment treaties with the purpose of adequately safeguarding the States right to regulate in the public interest within the existing international legal framework on foreign investment per se, while curtailing the enhanced interpretative discretion vested to private arbitrators by the conventional vaguely drafted and ill-defined investment treaties. ${ }^{52}$ This attempt has been furthered by introducing a series of obligations upon investors which is vital to rectify the unbalanced content of conventional IIAs. ${ }^{53}$ Furthermore, a number of attempts have been taken to address the increased backlash against the ISDS mechanism, due to its impact on states' right to regulate in the public interest, among other reasons. Several states have been calling for ISDS reform, by creating appeals mechanisms or a multilateral investment court, by emphasizing state-state dispute settlement or by turning to alternative dispute resolution methods. ${ }^{54}$

$5^{1}$ See generally Muthucumaraswamy Sornarajah, Resistance and Change in the International Law on Foreign Investment (United Kingdom: Cambridge University Press, 2015).

$5^{2}$ For a detailed discussion on such attempts with respect to Indirect Expropriation, see Suzy Nikièma, Best Practices-Indirect Expropriation (Manitoba: International Institute for Sustainable Development, 2012); UNCTAD, Expropriation-UNCTAD Series on Issues in International Investment Agreements II, (New York and Geneva: United Nations, 2012). With respect to FET see UNCTAD, Fair and Equitable Treatment-UNCTAD Series on Issues in International Investment Agreements II (New York and Geneva: United Nations, 2012). With respect to definitions of the terms "investment" and "investor" see UnCTAD, Scope and Definition-UNCTAD Series on Issues in International Investment Agreements II (New York and Geneva: United Nations, 2012). With respect to MFN treatment see UNCTAD, Most-Favoured-Nation Treatment-UNCTAD Series on Issues in International Investment Agreements II (New York and Geneva: United Nations, 2010); Suzy Nikièma, IISD Best Practices Series: The Most-Favoured-Nation Clause in Investment Treaties (Manitoba: International Institute for Sustainable Development, 2012).

53 See for example The 2016 Morocco-Nigeria BIт. For a discussion on this BIT see Tarcisio Gazzini, "The 2016 Morocco-Nigeria вIт: An Important Contribution to the Reform of Investment Treaties," Investment Treaty News, 8, no 3 (2017):3.

54 See generally UnCTAD, "Reform of Investor-State Dispute Settlement: In Search of a Roadmap," IIA Issues Note, no. 2, June, 2013. For a detailed discussion on appeals mechanisms see David Gantz, "An Appellate Mechanism for Review of Arbitral Decisions in Investor-State Disputes: Prospects and Challenges," Vanderbilt Journal of Transnational Law 39, no. (2006): 39; Mark Feldman, "Investment Arbitration Appellate Mechanism Options: Consistency, Accuracy, and Balance of Power," ICSID Review-Foreign Investment Law Journal 32, no. 3 (2017): 528. For a detailed discussion on Multilateral Investment Court See Gus Van Harten, "A Case for an International Investment Court" (Society of International Economic Law Inaugural Conference, Geneva, 2008); Catharine Titi, "The European Union's Proposal for an International Investment Court: Significance, Innovations and Challenges Ahead" Transnational Dispute Management 1 (2017). 
However, the balancing efforts undertaken by some of the States entails the risk of reversing the system towards the other edge of the spectrum i.e., protecting public interests of States at the expense of private rights of foreign investors. The protection of the latter is the fundamental purpose of the international system for the protection of foreign investment. One of the best examples in this respect is the 2016 Indian Model BIT which demonstrated the country's willingness to deprive foreign investors of fundamental treatment standards such as FET and MFN, while providing the country with an enhanced regulatory space. ${ }^{55}$ The model в вт has limited the accessibility of the ISDS mechanism by emphasising the need to exhaust local remedies for a period of at least five years prior to initiating international arbitration. ${ }^{56} \mathrm{In}$ addition, Brazil has formulated an agreement focusing on investment facilitation and cooperation instead of promotion and protection, which is known as Cooperation and Facilitation Investment Agreement (CFIA). ${ }^{57}$ This model agreement has excluded indirect expropriation from its purview, ${ }^{58}$ while including clauses on corporate social responsibility, ${ }^{59}$ provisions against corruption, ${ }^{60}$ as well as a guarantee that State parties are able to adopt, maintain or enforce any measure it deems appropriate to ensure that investment activities are undertaken according to labour, environmental and health legislations of the host State. ${ }^{61}$ More importantly, CFIA focuses on the prevention of disputes by creating a mechanism i.e., ombudsman or focal point to provide foreign investors with a solution with respect to their queries, while coordinating with the governmental organs. ${ }^{62}$ The CFIA also provides for the establishment of a Joint Committee for State-state cooperation and

See further Michele Potestà, State-to-State Dispute Settlement Pursuant to Bilateral Investment Treaties: Is There Potential?, N. Boschiero et al. eds., International Courts and the Development of International Law (New York, NY: Springer Berlin Heidelberg, 2012): 753. Anthea Roberts, "State-to-State Investment Treaty Arbitration: A Hybrid Theory of Interdependent Rights and Shared Interpretive Authority", Harvard International Law Journal 55, no. 1 (2014): 1.

55 Prabhash Ranjan and Pushkar Anand, "The 2016 Model Indian Bilateral Investment Treaty: A Critical Deconstruction," Northwestern Journal of International Law \& Business 38, no. 1 (2017);

56 Ranjan and Anand, "The 2016 Model Indian Bilateral Investment Treaty."

57 For a detailed discussion on CFIA see José Henrique Vieira Martins, "Brazil's Cooperation and Facilitation Investment Agreements (CFIA) and Recent Developments," Investment Treaty News 6, no. 3 (2017).

$5^{8}$ Article 7 of CFIA.

59 Article 14 of CFIA.

60 Article 15 of CFIA.

61 Article 16 of CFIA.

62 Article 18 of CFIA. 
dispute prevention - a mechanism in which envoys of the investors and governments involved can share their opinions regarding the concerns raised by the investors and seek to address them by finding common ground. ${ }^{63}$ As a result, the Brazilian model does not provide for ISDS, while making StateState arbitration the last resort in determining the conformity of the impugned measure with the Agreement. ${ }^{64}$

Following a more radical approach, in 2015, South Africa enacted domestic legislation which governs matters relating to the protection of foreign investments, while denouncing some of its BITs and the ISDS system more generally. The South African Protection of Investment Act has resulted in effectively dragging the protection of foreign investment into the domestic legal sphere. ${ }^{65}$ It aims at protecting foreign investment in accordance with and subject to the country's Constitution with the purpose of striking a better balance between the public interest and the rights and interests of investors. ${ }^{6} 6$ Similar to the Brazilian approach, the Act also does not provide protection against indirect expropriations, while providing them with reduced substantive protection compared to the protection accorded by IIAs. With respect to dispute settlement, the Act provides for two types of domestic remedies i.e., seeking mediation or approaching any competent court, independent tribunal or statutory body to resolve disputes relating to an investment. ${ }^{67}$ The Act, however, foresees the possibility of international arbitration which can be initiated after obtaining the government's consent, subject to the exhaustion of domestic remedies. ${ }^{68}$ Contrary to such radical approaches, the USA and Canada have revised their Model BITs in a way which limits the interpretative discretion of arbitrators, particularly regarding two provisions that had been subjected to expansive interpretation in arbitral tribunals; namely the FET clause and the expropriation clause. ${ }^{69}$ The fundamental purpose of

63 Article 17 of CFIA.

64 Article 24 of CFIA. However, Article 13-Corporate Social Responsibility; Article 14 (1) - Investment Measures and Combating Corruption and Illegality; and Article 15 (2) - Provisions on Investment and Environment, Labor Affairs and Health may not be subjected to arbitration.

65 For a detailed discussion on The South African Protection of Investment Act see Tarcisio Gazzini, "Rethinking The Promotion and Protection of Foreign Investments: The 2015 South Africa's Protection Investment Act," www.ssrn.com/abstract $=2960567$.

66 Article 4 of Protection of Investment Act, 2015.

67 Article 13 of Protection of Investment Act, 2015.

68 Article 13 of Protection of Investment Act, 2015.

69 For a discussion on The 2012 US Model BIT see Lise Johnson, "The 2012 US Model BIT and What the Changes (or Lack Thereof) Suggest about Future Investment Treaties" Political Risk Insurance Newsletter 3, no. 2 (2012). 
this endeavour is to prevent arbitral tribunals from interpreting these two substantive treaty protections in a manner which overly protects the interests of foreign investment to the detriment of States' right to regulate. For example, Annex B of the 2012 US Model BIT articulates that the treaty reflects customary international law regarding the obligation of States with respect to expropriation, and further stipulates to treat foreign investors in accordance with customary international law, including FET and full protection and security. By clarifying the term "customary international law" as "a general and consistent practice of States that they follow from a sense of legal obligation," 2012 US Model BIT closely guide arbitrators' interpretations regarding the minimum standard of treatment and expropriation. Furthering this effort, Annex B of the 2012 US Model BIT provides basic factors that should be taken into consideration by an arbitral tribunal when determining the occurrence of an indirect expropriation. ${ }^{70}$ With respect to the ISDS mechanism, the USA's contemporary approach has become somewhat doubtful in the context of North American Free Trade Agreement (NAFTA) renegotiations, ${ }^{71}$ while some suggestions have been made to make the ISDs mechanism more institutionalised by adding another layer i.e., an appellate mechanism, ${ }^{72}$ whereas the EU is promoting the idea of establishing a two-tiered multilateral investment court. ${ }^{73}$ To detailed, the EU-Vietnam FTA of 2015 provides for the establishment of a permanent investment tribunal and an appeal tribunal, whilst Comprehensive Economic Trade Agreement (CETA) of 2016 signed between EU and Canada anticipates setting up a permanent tribunal consists of 15 members to entertain claims by investors.

It is thus apparent that the international system for the protection of foreign investment is currently undergoing a paradigm shift which is driven by the urgency of ensuring the balance between private interests of foreign

70 These factors basically include the economic impact of the government action, the extent to which the government action interferes with distinct, reasonable investment-backed expectations, and the character of the government action.

71 Christian Leathley and Conor Doyle, "NAFTA Renegotiation: Is Ds Reform Objectives," Arbitration Notes, August, 2017, https://hsfnotes.com/arbitration/2017/08/07/nafta -renegotiation-isds-reform-objectives/.

72 Gantz, "An Appellate Mechanism for Review of Arbitral Decisions in Investor-State Disputes."

73 For a discussion on the multilateral investment court see Sergio Puig, "The Death of ISDS?, Kluwer Arbitration Blog, (blog), March 16, 2018, http://arbitrationblog.kluwerarbitration .com/2018/03/16/the-death-of-isds; Louise Woods, "Fit for purpose? The EU's Investment Court System," Kluwer Arbitration Blog, (blog), March 23 2016, 2018, http://arbitration blog.kluwerarbitration.com/2016/03/23/to-be-decided/. See further Bonnitcha, Poulsen, and Waibel, The Political Economy of the Investment Treaty Regime, 30. 
investors and public rights of host States substantively, as well as procedurally. However, measures indicate the risk of reversing the investment treaty regime towards the other edge of the spectrum i.e., protecting public interests of States at the expense of private rights of foreign investors, counter to genuine efforts that have been taken to facilitate a proper balance between private and public interests, such as including non-investment concerns into the text of investment treaties, closely guiding arbitrators' interpretations regrading core investments disciplines and introducing a series of obligations upon investors. This is mainly because they demonstrate the inclination towards the depriving foreign investors of the rights traditionally afforded by fundamental investment disciplines. This inclination is accompanied by attempts to provide host States with an enhanced regulatory autonomy by including general exceptions and excluding certain measures such as tobacco control from the purview of the regime. ${ }^{74}$ Furthermore, the balancing endeavour lacks coherence, as different States have advanced different substantive and procedural strategies to address the strong backlash against the existing system. This is mainly because certain States have unilaterally attempted to address the very issues of balancing private rights of foreign investors with public rights of host States, instead of adopting a multilateral approach thereon. Such unilateral attempts have furthered the fragmented nature of international investment governance, while driving the existing system of protecting of foreign investment towards a crisis. Therefore, the success of the rebalancing endeavour in the investment treaty regime has become somewhat disputed, and the absence of a multilateral approach has resulted in different substantive and procedural strategies being proposed to address the strong backlash against the regime. Such divergent approaches, some of which prioritise host States' enhanced regulatory authority and increased leverage in the settlement of investment disputes, make the balancing endeavour a reactive one which seeks to overturn the fundamental basis of the investment regime, instead of merely reforming it. At a time when international investment governance is at a stake, China is rising as a global superpower with phenomenal economic growth and experiences balanced inbound and outbound flows of foreign investment. Against this background, the next part of the paper expects to ascertain whether China's rise would be helpful to improve the coherence of the international investment governance or whether it would result in a further disintegration. 
Since the commencement of the "Open Door" policy in late 1970s, China acceded to leading multilateral institutions as a part of the country's broad agenda to effectively reintegrate into the existing international order, particularly the world economy. ${ }^{75}$ In 1980 , China resumed its membership at the WB and International Monetary Fund (IMF). China requested to resume its status as a contracting party to the GATT in July 1986 and, in 2001 the country became a member of WTO. China's accession to WB, IMF and wTO demonstrates the country's willingness to assimilate into the west-driven multilateral institutional framework which has being directing international economic governance since the inception of post-World War II global order. With respect to foreign investment in particular China joined the Multilateral Investment Guarantee Agency (MIGA) in 1988. In 1990, China singed the Washington Convention and ratified it in 1993, marking a paradigm shift in the country's conventional approach which perceived ICSID as a threat to state sovereignty and national jurisdiction. ${ }^{76}$ These two steps demonstrated China's immersion into the institutional framework of international investment governance in which MIGA and ICSID play important roles to provide foreign investors with greater pecuniary and legal protection against the political risks that they face when operating in host States.

Similar progress has seen with respect to China's approach towards international investment law norms on the protection of foreign investment. China's BIT programme has gradually come to reflect widely-accepted protection standards accorded to foreign investors by the Global North. ${ }^{77}$ For example, at the

75 For a critical discussion on China's integration into the current international order see Li, "Rising from Within."

76 Stephan Schill, "Tearing down the Great Wall—the New Generation Investment Treaties of the People's Republic of China," Cardozo Journal of International and Comparative Law 15, no. 1 (2007): 73 .

77 For a detailed discussion on China's BIT programme see generally Wenhua Shan and Jinyuan Su, eds., China and International Investment Law: Twenty Years of ICSID Membership, Silk Road Studies in International Economic Law, volume 1 (Leiden; Boston: Brill Nijhoff, 2015); Kong Qingjiang, "Bilateral Investment Treaties: The Chinese Approach and Practice," in Sik Swan, et al., eds., Asian Yearbook of International Law (Leiden, Boston: Martinus Nijhoff Publishers, 1998/1999); Axel Berger, “China's New Bilateral Investment Treaty Programme: Substance, Rational and Implications for International Investment Law Making" (American Society of International Law International Economic Law Interest Group 2008 biennial conference, Washington, D.C, 2008), www.die-gdi.de/ uploads/media/Berger_ChineseBITs.pdf; Axel Berger, "The Politics of China's Investment Treaty-Making Program" in Tomer Broude, Marc Busch and Amelia Porges, eds., The Politics of International Economic Law (New York: Cambridge University Press, 2011): 
beginning China generally did not provide foreign investors with the NT, yet in its second phase China provided foreign investors with NT subject to the country's domestic laws and regulations - an approach known as the "best effort clause". Moving further, it concluded BITs with developed countries such as the 2001 China-The Netherlands BIT, in which China has undertaken a commitment with respect to NT by agreeing not to increase existing discriminatory treatment and gradually abolish measures discriminating against foreign investors. In addition, China has deviated from its conventional practice of not integrating customary international law into its economic treaties, the formation of which was understood by China as a process largely dominated by Western hegemonic powers leaving a little room for developing countries. ${ }^{78}$ For example, in the 2008 China-Mexico BIT accepted the "international law minimum standard of treatment of aliens as evidence of State practice and opinio juris" as the minimum standard of treatment to be afforded to foreign investments under the FET and FPS clauses. ${ }^{79}$ In the 2012 China-Canada BIT, China agreed to accord foreign investors FET and FPS in accordance with international law, limiting the scope of these two standards of treatment to the protection accorded by "the international law minimum standard of treatment of aliens as evidenced by general State practice accepted as law." ${ }^{80}$ It is thus apparent that China's BIT programme has seen the gradual adoption of international investment law norms shaped by the western ideologies.

It can be accordingly argued that China's rise has not yet institutionally or ideologically challenged the current framework of international investment governance, rather integrating into it effectively without disputing its normalcy. China in particular has not taken any radical measures such as Brazil,

162; Cai Congyan, "CHINA-US BIT Negotiations And the Future of Investment Treaty Regime: A grand Bilateral Bargain with Multilateral Implication," Journal of International Economic Law 12, no. 2 (2009): 457; Kate Hadley, "Do China's BITs Matter? Assessing the Effect of China's Investment Agreements on Foreign Direct Investment Flows, Investors' Rights, and the Rule of Law," Georgetown Journal of International Law 45, no. 1 (2013): 255; Stephan Schill, "Tearing Down the Great Wall”; Wang, "Toward A Global Investment Governance Framework."

78 For example Article 143(1) of China-New Zealand FTA employs the term of 'commonly accepted rules of international law,' instead of the term of 'customary international law'. See further Axel Berger, "The Politics of China's Investment Treaty-Making Program". Article 5 of the 2008 Agreement between the Government of the United Mexican States and the Government of the People's Republic of China on the Promotion and Reciprocal Protection of Investments.

8o Article 5 of the Agreement between the Government of Canada and the Government of the People's Republic of China for the Promotion and Reciprocal Protection of Investments. 
India or South Africa to respond to the backlash against the international system of protecting foreign investments through IIAs and the ISDS mechanism. However, the content of some of recent Chinese BITs indicates the country's receptiveness towards making investment treaties more balanced by curtailing the interpretative discretion of arbitrators and providing more regulatory space for host States. For example, in the 2012 Japan-Korea-China Trilateral Investment Treaty, China has agreed to a protocol on indirect expropriation which resembles to the "interpretative annexes"81 included in the 2012 US Model BIт and the 2004 Canadian Model BIT, which require arbitrators to determine indirect expropriation on a case-by-case basis by means of a fact-based inquiry, while considering the factors specified in the treaty itself. In addition, some of the recent Chinese BITs have articulated the significance of public welfare objectives. For example, the preambles to the 2013 China-Tanzania вIт, the 2002 China-Trinidad and Tobago BIT, and the 2012 China-Canada BIT stipulate that the promotion and protection of foreign investment should be realised without jeopardizing public policy objectives such as public health, safety and environmental protection and promoting the respect for corporate social responsibility and sustainable development. Furthermore, recent Chinese вIтs include a number of treaty-exceptions which are important to maintain a better balance between the protection of foreign investment and a State's right to regulate in certain circumstances. For example, the 2009 ASEAN-China BIT includes a general exception clause and an essential security exception clause, as well as recognising State parties' ability to limit the transfer of currency if they are undergoing serious economic disturbances. The 2012 China-Canada BIт includes an extensive general exception clause which covers a range of issues such as cultural industries, environmental measures, and prudential measures to which the treaty is not applicable or do not prevent contracting State parties from adopting or maintaining necessary measures identified as exceptions under the BIT. Regarding the ISDS mechanism, China's flexibility is clearly indicated in the Australia-China FTA of 2015, which provides State parties with an enhanced leverage over the ISDS mechanism, reducing investors' control over it. ${ }^{82}$

81 For a discussion on "the interpretative annexes" in US and Canadian Model BITs see Jonathan Bonnitcha, Substantive Protection under Investment Treaties: A Legal and Economic Analysis, Cambridge Studies in International and Comparative Law (Cambridge, United Kingdom: Cambridge University Press, 2014).

82 For a discussion on the investment dispute settlement mechanism under the AustraliaChina FTA of 2015 Heng Wang, see "The RCEP and Its Investment Rules: Learning from Past Chinese FTAs," The Chinese Journal of Global Governance 3 (2017): 160. 
China has had a limited, but ultimately positive, experience in international arbitration as a method of resolving investment disputes between foreign investors and the host States. Due to its conventional skepticism on international law and strong emphasis on state sovereignty, China initially disinclined to accept international arbitration as a method of resolving investment disputes between foreign investors and the host state. ${ }^{83}$ However, subsequently, it recognised international arbitration as a method of resolving investment disputes only with respect to the dispute involving or relating to the amount of compensation payable in an event of expropriation. This approach was further liberalised by allowing foreign investors to submit any investment dispute to an international arbitral tribunal on the condition that both parties to the dispute should agree thereto. Only in late 199os did China conclude BITs with more comprehensive clauses on international arbitration by concluding the China-Barbados B IT of 1998 which allows foreign investors directly and unilaterally recourse to international arbitration to resolve any investment dispute under the treaty. Accordingly, recent Chinese BITs such as the 2013 ChinaTanzania BIT and the 2011 China-Uzbekistan BIT include comprehensive dispute settlement clauses. Despite China's increased affording for the ISDS mechanism, it was not utilized neither by foreign investors nor Chinese investors, for a considerable period of time. On the contrary, this decade has seen China's slowly but increasing appearance in IsDs cases-five known claims by Chinese investors and three known claims against China. ${ }^{84}$ Another two ISDS cases have been recently registered with ICSID-one of them was initiated by a Chinese investor against Laos and another by a German investor against China. It is apparent that during this decade, China has increased engagement

83 For a detailed discussion on China's gradually changing stance towards ISDS mechanism, see Shan and Su, China and International Investment Law; Qingjiang, "Bilateral Investment Treaties"; Berger, "China's New Bilateral Investment Treaty Programme”; Berger, "The Politics of China's Investment Treaty-Making Program"; Congyan, "CHINA-US BIT Negotiations"; Hadley, "Do China's BITs Matter?”; Schill, “Tearing Down the Great Wall”; Wang, "Toward A Global Investment Governance Framework." See further Leon Trakman, "Geopolitics, China and Investor-State Arbitration" in Lisa Toohey, Colin Picker, Jonathan Greenacre, eds., China in the International Economic Order: New Directions and Changing Paradigms (New York, NY: Cambridge University Press, 2015): 268; Valentina Vadi, "Law, Culture, and the Politics of Chinese Outward Foreign Investment" in Paolo Farah and Elena Cima, eds., China's Influence on Non-Trade Concerns in International Economic Law (London; New York Routledge: Routledge, 2016); 98.

84 Dilini Pathirana, "A Look into China's Slowly Increasing Appearance in ISDS Cases." See further Dilini Pathirana, "Making an Arbitration Claim under Chinese BITs: Some Inferences from Recent ISDS Cases," The Chinese Journal of Comparative Law 5, no. 2 (2017): 420 . 
as a home or host state, while several states have been calling for reform of the ISDS mechanism or replacing it with other dispute settlement mechanisms. However, it remains to be seen whether China would support reform initiatives or whether its increasing role in the context of ISDS could make it more inclined to maintain the existing regime. ${ }^{85}$ It has been argued that China may be reluctant to replace the ISDS mechanism and is likely to be a "semi-systemic reformer, seeking to retain investment treaty arbitration with incremental improvements but subject to an appellate body." 86

At the same time, China's recent stance towards foreign investment signals its new-found enthusiasm for investment liberalisation. China in its recent BITs such as China-Korea BIT of 2007 and China-New Zealand PTIA of 2008, as well as FTAs such as China-Peru PTIA (2009) have provided foreign investors with the pre-establishment MFN treatment by including the phrase "admission" or "establishment" into the investment activities that are covered by the M FN clause. This articulation has been identified as a small but progressive step that has taken the country towards investment liberalisation. ${ }^{87}$ In addition, by deviating from its conventional approach towards the pre-establishment rights i.e., not providing foreign investors with the pre-establishment rights, particularly NT, China has agreed to adopt the 'pre-establishment model', marking a giant step in its investment treaty-making practice and the country's approach towards the investment liberalization. To be detailed, China has agreed to provide foreign investors with pre-establishment NT based on the negative list approach in the context of US-China BIT negotiations, whilst this approach has been already implemented in China's Pilot Free Trade Zones (FTZs), which is expected to be fully implemented nationwide in $2018 .{ }^{88}$ This will be a beacon for the upgrading process of the China-ASEAN FTA and forward working programme of China-Australia FTA in relation to which market access has been a crucial issue, as well as the China-EU BIT which is under negotiation. Moving

85 Mark McLaughlin, "Global Reform of Investor-State Arbitration: A Tentative Roadmap of China's Emergent Equilibrium," The Chinese Journal of Comparative Law 6, no. 1 (June 1, 2018): 73-102.

86 Anthea Roberts, "Incremental, Systemic, and Paradigmatic Reform of Investor-State Arbitration," American Journal of International Law, (forthcoming).

87 Axel Berger, Investment Rules in Chinese Preferential Trade and Investment Agreements: Is China Following the Global Trend towards Comprehensive Agreements? (Bonn: Dt. Inst. für Entwicklungspolitik, 2013): 11.

88 For a detailed discussion on US-China BIT negotiations see Peterson Institute for International Economics, "Toward a US-China Investment Treaty," PIIE Briefing 15, no 1 (2015); Pianpian Huang and Jake Parker, "Does the New Market Access Negative List System Indicate Opening Up?", The Us-China Business Council, November 11, 2015, https://www .uschina.org/does-new-market-access-negative-list-system-indicate-opening. 
further, in the recently concluded investment agreement between mainland China and Hong Kong, as a component of the framework of the Mainland and Hong Kong Closer Economic Partnership Arrangement (CEPA), China commits to provide NT to investments and investors, based in Hong Kong, with respect to the establishment of investments. ${ }^{89}$ At the domestic level as well, China has articulated its commitment to implement a regulatory system for foreign capital based on pre-establishment NT with a negative list approach in the country's 13th Five-Year Plan (2016-2020). The 13th Year Five Plan further articulates the desire to unify laws and regulations for domestic and foreign capital, culminating in the 2015 Foreign Investment Law. These stances thus can be considered as clear indications of China's increasing espousal of the notion of investment liberalization, parallel to the country's emergence as a leading global investor.

It is thus apparent that China's rise has not yet challenged the existing international system of protecting foreign investment. Instead, China has been increasingly engaged with the institutional and ideological framework on the promotion and protection of foreign investment developed by the West since the beginning of post-World War II global order in which international investment governance is driven mainly according to the Washington Consensus. Contrary to other major developing States such as Brazil, India and South Africa, China has not still shown any radical response to the backlash against the current system of protecting foreign investment. Instead, the country has adopted a responsive approach towards the balancing endeavour, while being flexible to other negotiating parties' concerns regarding the substantive and procedural aspects, particularly in BITs with Canada and the FTA with Australia. In particular, China has followed a progressive approach towards investment liberalisation by committing to adopt the negative list approach with NT and by concluding IIAs which expand market access to investors from Hong Kong. Complementing the country's progressive approach towards the promotion and protection of foreign investment, China has become a supporter and defender of economic globalisation which is currently under attack. China's positive approach towards the multilateralism in global economy is a clear indication of the country's increasing political ambition to play an enhanced role particularly in the global economic governance by reforming it in a manner which provides more room to the Global South and fighting against protectionism. ${ }^{90}$ This context calls for a discussion on the extent to

89 Article 5 of the China-Hong Kong CEPA Investment Agreement of 2017.

9o See for example Xi Jinping, "Jointly Shoulder Responsibility of Our Times, Promote Global Growth," World Economic Forum Annual Meeting-2017, 17 January 2017, http://www 
which China has supported the promotion of multilateralism in international investment governance, as well as the country's potential to provide leadership make the regime less fragmented and more coherent.

\section{The Effect of China's Rise on the International Investment Governance-Prospects and Challenges}

China's potential to provide the leadership to make international investment governance more coherent was demonstrated during its presidency in the G20 - the central forum for international cooperation on financial and economic questions. This is because China provided the political leadership to outline the architecture of a comprehensive framework on international investment by creating G2o's Working Group on Trade and Investment which worked towards the adoption of 'G2o Guiding Principles for Global Investment Policymaking' (The G2o Guiding Principles).91 The Guiding Principles which are non-binding in nature, were endorsed by the trade ministers of G2o with the purpose of fostering an open, transparent, and global policy environment conducive to investment, expecting that they will encourage coherence in national and international policy making, as well as will provide enhanced predictability and certainty for business to support their investment decisions. Accordingly, the G2o Guiding Principles are of importance to provide political guidance and common directions for investment policymaking both at the national and international levels, while contributing to "outline the architecture of a comprehensive framework on international investment". Furthering the country's effort to facilitate foreign investment, in 2017, China joined with a group of States which desire to work on a multilateral framework on investment facilitation under the auspices of the wTO-an effort to which the USA has not yet participated. The USA's nonparticipation in this attempt will undoubtedly provide China with an opportunity to shape future global rules on investment facilitation, in particular, under the auspices of the WTO. In general, it will be a good opportunity for China to show the country's potential to drive the international economic governance in a global context where the

.china.org.cn/node_7247529/content_40569136.htm. See further "Highlights of Xi's keynote speech at Boao Forum — 2018," China Daily, April 10, 2018, http://www.chinadaily.com .cn/a/201804/10/WS5acc15a6a3105cdcf6517259.html.

91 For a discussion on The G2o Guiding Principles see Karl Sauvant, "After successes at Hangzhou G20, it's Germany's turn to keep momentum going," ShanghaiDaily.com, January 13, 2017, ccsi.columbia.edu/files/2017/01/KPS-op-ed-China-G20-Shanghai-Daily -13-Jan-17.pdf. 
political leadership of the USA is declining under the Trump administration, which favours bilateralism instead of multilateralism regarding issues on international trade. ${ }^{92}$

However, the USA's new-found resistance against multilateralism particularly in the context of the global economy together with other events such as the UK's withdrawal from the EU, collectively demonstrate the current global trend of increasingly advocating deglobalisation by intensified nationalism, protectionism and populist movements which oppose the global integration of capital, trade and people. It is, thus, apparent that the current global context itself has become a challenge to China to effectively steer international investment governance by promoting investment liberalisation which is vital to stimulate economic globalisation. This is mainly because the economic nationalism implemented through protectionist and interventionist government policies will certainly hamper China's attempt to promote investment liberalization, in particular and economic globalisation, in general. The challenge has been already experienced by Chinese investors such as the Ralls Corporation who sought to invest in the USA, yet was denied after review by the Committee on Foreign Investment in the United States (CFIUS) for national security reasons. ${ }^{93}$ European countries also have raised national security concerns with respect to Chinese investments, mainly in the context of mergers and acquisitions (M\&As) not only by Chinese State Owned Enterprises (soes) but also by privately-held Chinese companies. For example, the clearance given to the voluntary public takeover offer made by Fujian Grand Chip Investment Fund LP, controlled by Chinese tycoon Zhendong Liu, for German chip maker Aixtron was withdrawn by the German authorities due to security concerns raised by the USA..$^{94}$ Further concerns have been raised by European countries, particularly the lack of reciprocity in market access and unfair competition

92 See for example James Nolt, "Trump and Trade Bilateralism," World Policy, January 12, 2017, https://worldpolicy.org/2017/o1/12/trump-and-trade-bilateralism/; Geoffrey Gertz, "What will Trump's embrace of bilateralism mean for America's trade partners?" Brookings, February 8, 2017, https://www.brookings.edu/blog/future-development/2017/02/08/what -will-trumps-embrace-of-bilateralism-mean-for-americas-trade-partners/.

93 For a detailed discussion on national security review with respect to foreign investment in USA, particularly the Chinese investments see Peterson Institute for International Economics, "Toward a US-China Investment Treaty," PIIE Briefing 15, no, 1(2015). See further Karl Sauvant Karl Sauvant and Michael Nolan, "Reactions to China's cross-border investment and international investment law" in Martina Fuchs et al., eds., Managing Culture and Interspace in Cross-border Investments (New York and London: Routledge, 2017): 98.

94 Guy Chazan, "Germany expands powers to block takeovers," Financial Times, July 13, 2017, https://www.ft.com/content/5087c106-66fc-11e7-9a66-93fb352baife. 
by heavily subsidised Chinese soes, while provoking protectionist measures against Chinese investments in some EU countries. ${ }^{95}$ For example, Germany recently approved rules restricting the selling of strategically vital enterprises to investors from outside the EU, mainly due to concerns about China's acquisition of German expertise. ${ }^{96}$ At the EU level, the European Commission expects to establish a common European framework for screening FDI into the EU, mainly with respect to critical infrastructure and sensitive technologiestwo of the main areas in which increased Chinese investments are prevalent. ${ }^{97}$

As within American and European contexts, Chinese investors are facing intensified public and political hurdles in rest of the world. For example, China's attempt to secure a greater hold of Australia's resource sector, such as unsuccessful bid made by China Nonferrous Metal Mining Group's to acquire controlling stake in Australian mining company Lynas, has provoked a hostile response against Chinese investments in Australia and raised concerns on keeping Chinese investors away from controlling the country's natural resources. ${ }^{98}$ National security has also been used as a ground for blocking Chinese investment in Australia, as exemplified in the case of the proposed joint venture between Wugang Australia Resources-a wholly owned unit of Chinese state-owned Wuhan Iron and Steel, and Australia's Western Plains Resources, which was rejected by the Defence Department due to the project's possible threats on national security. In 2008, Australia adopted a new policy requiring the Treasurer to examine specific issues including the national security when considering investment applications submitted by foreign governments and their agencies. Triggered by concerns about foreign States' influence in its economy, particularly including the country's oil sands business, Canada also

95 For a detailed discussion on Chinese investments in European countries See John Seaman, Mikko Huotari, and Miguel Otero-Iglesias, eds., "Chinese Investment in Europe A Country-Level Approach" (The European Think-tank Network on China (ETNC) December 2017).

96 Maria Brakalova, Germany Tightens Restrictions On Foreign Investment From Outside The EU," Dentons, July 31, 2017, https://www.dentons.com/en/insights/alerts/2017/july/ 31/germany-tightens-restrictions-on-foreign-investment-from-outside-the-eu; Mikko Huotari, “Germany's Changing Take on Chinese Direct Investment: Balancing Openness with Greater Scrutiny" in John Seaman, Mikko Huotari, and Miguel Otero-Iglesias, eds., "Chinese Investment in Europe A Country-Level Approach", 61.

97 "State of the Union 2017-Trade Package: European Commission proposes framework for screening of foreign direct investments," European Commission-Press release database, European Commission, September 14, 2017, http://europa.eu/rapid/press -release_IP-17-3183_en.htm.

98 "China fails in another bid for resources firm," The Sunday Morning Herald, September 24, 2009, https://www.smh.com.au/business/china-fails-in-another-bid-for-resources-firm -20090924-g4l7.html. 
announced modifications to the review process relating to the investments by foreign soEs. ${ }^{99}$ These modifications have resulted in expanding the definition of soEs in a manner which includes not only "entities that are owned or controlled by a foreign government but also entities that are influenced, directly or indirectly, by a foreign government," ${ }^{100}$ posing challenges to Chinese investors in establishing their character under the Canadian Law. In addition, Chinese investments have been criticised due to their environmental impact, poor working conditions, and employment of Chinese workers instead of local man power, particularly with respect to investments in Africa. This has been expounded as China' attempt to be a new colonial power-an allegation that has been rejected by the Chinese government. ${ }^{101}$ Accordingly, the rising skepticism in relation to Chinese investments has caused a corresponding rise of national investment screening mechanisms.

The backlash against the existing international system for the protection of foreign investment can be identified as another challenge that China will have to face if the country wishes to continue with the system as it is. This is mainly because most of the States, including the major developing States of the Global South, have already taken radical steps to alter the existing system by lowering the substantive and procedural protections that have conventionally been accorded to foreign investors under IIAs, while providing hosts States with an enhanced regulatory space and more leverage over the settlement of investment disputes. As discussed, three States i.e., Brazil, India and South Africa out of five BRICS countries are at the fore of radically altering the existing system and this, scenario will undoubtedly hinder China's strength if the country wishes to push the international community towards adopting a multilateral legal framework on foreign investment based on the ISDS mechanism. ${ }^{102}$ It is further doubt whether Russia will support such an attempt because Russia has already demonstrated its dismay about the contemporary system by withdrawing from the Energy Charter under which the country has been found liable in the arbitration proceedings brought by former shareholders in the defunct Russian energy company Yukos, the award for which was the largest

99 Donald Greenfield and Beth Riley, "Canadian Government Adjusts Rules for Foreign Investment," Mondaq, December 18, 2012, http://www.mondaq.com/canada/x/212308/.

100 Greenfield and Riley.

101 See for example Elizabeth Manero, "China's Investment in Africa: The New Colonialism?," Harvard Political Review, February 3, 2017, http://harvardpolitics.com/world/chinas -investment-in-africa-the-new-colonialism/.

102 For a detailed discussion on China and BRICs, particularly including constrains of the BRICS see Li, "Rising from Within." 
compensation in arbitral history. ${ }^{103}$ This situation is notably different from the cohesion that BRICS countries showed in establishing the New Development Bank (NDB), previously known as the BRICs Development Bank, as well as the support that China received in establishing the Asian Infrastructure Investment Bank (АIIB). At the same time, BRICS States' disjointed approach towards the current international investment governance shown by their separate initiatives, undermines China's desire that these five States promote multilateralism in the context of global economic governance, in general. ${ }^{104}$

It is thus apparent that even though China's rise has not endangered the existing international system for the protection of foreign investment developed by the West, it will be difficult for China to drive the system forward mainly due to the backlash against the system in particular, and resistance against the economic globalisation in general. ${ }^{105}$ This difficulty will likely increase due to the emerging backlash against Chinese investments, which bolsters China's economic expansion, including its enhanced strategic presence and influence, while raising regional concerns particularly in Europe and Asia. At the same time, if China chooses to continue with the current the system by concluding conventional IIAs on bilateral or plurilateral basis focusing on the promotion and protection of foreign investment, whereas most of the other States tend to conclude investment treaties focusing on investment facilitation and corporation, this scenario will give rise to two sets of investment agreement furthering the fragmented nature of international investment governance. The fragmentation effect of China's rise on international investment governance is particularly looming in the context of China's vision for regionalization i.e., BRI which is expected to be accomplished by creating an

103 For a discussion on the legal implication on Russia's withdrawing from the Energy Charter see Tania Voon and Andrew Mitchell, "Ending International Investment Agreements: Russia's Withdrawal from Participation in the Energy Charter Treaty," Australian Journal of International Law Unbound 111, (2017): 46.

104 See for example Xi Jinping, "Remarks at the Press Conference of the BRICs Xiamen Summit," September 5, 2017, http://www.xinhuanet.com/english/2017-09/05/c_136586311 .htm.

105 With respect to resistance against Globalization see for example Prabhat Patnaik, "The Growing Resistance against Globalization," IDEAs Blogs, (blog), October 21, 2016, http:// www.networkideas.org/themes/economy-and-society/2016/10/the-growing-resistance -against-globalization/. For a discussion on Trump administration's impact on globalization see Laurence Chandy and Brina Seidel, "Donald Trump and the future of globalization,” Brookings, November 18, 2016 https://www.brookings.edu/blog/up-front/2016/11/18/donald -trump-and-the-future-of-globalization/. 
extensive network of infrastructure projects connecting East Asia with the Middle East and Europe. ${ }^{106}$

The implementation of this vision gives rise to a wave of China-led infrastructure development projects spread across Asia and Africa, which are vital to establish both the trajectories of BRI i.e., Silk Road Economic Belt (the Belt) and 21st Century Maritime Silk Road (the Road). As well as an intensified geopolitical rivalry stemming from increased Chinese infrastructure investments along the Belt and Road, these investments have already established a distinct category of infrastructure investment projects under the theme of BRI, giving rise to a wave of one-sided investment flows from Beijing to Asia, Africa, the Middle East and Europe. This scenario indicates that geographical fragmentation in the field of foreign investment may result from the infrastructure investment projects particular to the BRI and financed by China or China-led multilateral institutions such as the АІІв. This geographical fragmentation will be undoubtedly driven towards an ideological fragmentation in the international investment law governance, if China establishes a separate institutional and normative framework of BRI which, inter alia, articulates the rules applicable to investment projects of BRI. However, BRI remains an initiative which is not underpinned by a multilateral legal framework. Thus, IIAs which China has already concluded with a given state participants to the BRI and investment contracts which entered into between Chinese investors and relevant governmental authorities of host Stats remain as the two main means to ensure the protection of investments under the BRI.

Insofar as China relies on individually concluded IIAs to protect Chinese investments, the BRI is less likely to adversely affect the current international system for the protection of foreign investment. This is because, as discussed, China's IIAs mostly align with international investment law norms, despite their slight variations resulting from the time that such IIAs were concluded. At the same time, China's most recent BITs such as the 2013 China-Tanzania вIт and the 2011 China-Uzbekistan BIT clearly show that the country's inclination to conclude IIAs premised on the notion of promotion and protection of investment. This is perhaps unsurprising due to China's emergent position as

106 For a discussion on BRI see Giesla Grieger, "One Belt, One Road (OBOR): China's regional integration initiative," European Parliament Briefing, July, 2016; Diane Desierto, "China's 'One Belt, One Road' Initiative: Can A Bilaterally-Negotiated 'Globalization 2.0' Internalize Human Rights, Labor, and Environmental Standards?” EJIL: Talk!, (blog), May 16, 2017, https://www.ejiltalk.org/chinas-one-belt-one-road-initiative-can-a-bilater ally-negotiated-globalization-2-o-internalize-human-rights-labor-and-environmental -standards/; Vivienne Bath, "One Belt, One Road" and Chinese Investment, Sydney Law School Legal Studies Research Paper No. 16/98, November 2016. 
a global investor in general and the principal investor in the BRI in particular. It is thus apparent that the protection of Chinese investments will be one of the main considerations for China in its IIA negotiations, particularly with State participants to the BRI. Therefore, BRI can be identified as a force by which China is compelled to continue with IIAs premised on the promotion and protection of investments rather than investments facilitation and cooperation due the country's central position in the BRI as the principle source from which investments go to its peripheral State participants. Therefore, China's approach towards the IIAs in the context of BRI would largely align with the fundamental ideology on which existing international system for the protection of foreign investment is based, instead of the emerging notion of investment facilitation and cooperation, particularly dispute prevention. This remark is verified by China's two recent actions which indicate the country's willingness to "judicialise" the dispute settlement of the BRI, contrary to the country's conventional preference for negotiation over litigation to solve disputes.

First amongst them is launching investment arbitration rules by China International Economic and Trade Arbitration Commission (CIETAC) together with the Cietac Investment Dispute Resolution Centre in Beijing. ${ }^{107}$ This initiative is aimed at facilitating the BRI by providing Chinese investors with an independent and impartial forum for resolving investment disputes, avoiding possible bias against them in foreign forums due to a lack of understanding of Chinese law and practice. More importantly, the cietac Centre could be included either in investment contracts or incorporated into Chinese IIAs, adding a Beijing-located forum for the settlement of investment disputes, which would be favoured by Chinese investors over other available forums such as domestic courts in host States and Washington-based ICSID. In addition, China has recently launched international commercial courts, commonly referred to as BRI Courts [in Beijing ...], Xi'an and Shenzhen with the purpose of effectively resolving commercial disputes along the Belt and Road. ${ }^{108}$

107 For a detailed discussion on CIETAC arbitration rules see Meg Utterback et al., "CIETAC Investment Arbitration Rules," King \& Wood Mallesons, December 14, 2017, https://www .chinalawinsight.com/2017/12/articles/global-network/cietac-investment-arbitration -rules/; For a critical discussion on strengthening CIETAC with respect to investment arbitration in the context of BRI see Horia Ciurtin, "The Structural Implications of Belt-and-Road Arbitration: China's Legal Gamble across Eurasia," Kluwer Arbitration Blog (blog), March 19, 2018, http://arbitrationblog.kluwerarbitration.com/2018/03/19/ structural-implications-belt-road-arbitration-chinas-legal-gamble-across-eurasia/.

108 "New Courts for the Belt and Road Initiative," овоReurope, February 2018, http://www .oboreurope.com/en/bri-courts/; "China to Set up Belt and Road Dispute Courts in Beijing, 
These courts are expected to be modelled on the world's leading commercial dispute resolution centers such as the Dubai International Financial Center (DIFC) Courts and Singapore International Commercial Court (sICC). This attempt is also aimed at providing Chinese enterprises along BRI with Chinabased forums to settle their commercial disputes along the Belt and Road. When compared these two initiatives, it is apparent that CIETAC Investment Dispute Resolution Centre is particularly dedicated for investment disputes, whilst BRI Courts are generally dedicated to commercial disputes. Collectively, these two initiatives demonstrate China's desire to provide Chinese enterprises pursuing the BRI with Chinese forums to resolve their disputes due to number of factors such as the diversity of legal systems along the States in Belt and Road. Chinese enterprises would be more comfortable with these two China-based forums and thus, it likely to increase litigation if disputes arise in the context of BRI in future, instead of solving them diplomatically or settling down - traditional methods which China has favoured so far. At the same time, they signal China's desire to drag disputes relating to BRI including investment disputes into the sphere of Beijing moving them away from the domestic jurisdiction of the BRI participating States, as well as Western-based international forums particularly the ICSID.

With respect to investment-related disputes, ciEtac Investment Dispute Resolution Centre will be of vital significant to provide Chinese investors with an additional forum to raise their claims against host States. This addition will provide them with a way to avoid western-based international dispute settlement forums and domestic forums available in host States and thus, future investment contracts relating to BRI projects are likely to include this Centre as one of the arbitration forums for settling disputes. Incorporating these two forums into future Chinese IIAs with BRI participant States will be undoubtedly given priority by China in negotiating future treaties or renegotiating existing ones. In this context, China-based forums will become more popular amongst Chinese investors to solve their investment-related disputes, particularly in the context of BRI. This scenario would give rise to a growing Sino-centric investment jurisprudence specific to BRI and if so, establishment of CIETAC Investment Dispute Resolution Centre and BRI Courts will result in another ramification in international investment governance. That gives rise to a Beijing-based pole in investment jurisprudence, alternative to West or Washington-based pole, simultaneous operations of which remains to be seen. However, at this point, it is apparent that creating China-based forums

Xi'an, and Shenzhen," Silk Road Briefing, February 2, 2018, https://www.silkroadbriefing .com/news/2018/02/02/china-set-belt-road-dispute-courts-beijing-xian-shenzhen/. 
to settle investment disputes under the BRI is likely to have an adverse effect on already fragmented international investment governance further degrading cohesion. At the same time, increased investment disputes relating to highly strategic Chinese infrastructure projects along the Belt and Road, such as the Colombo Port City Project in Sri Lanka has probably made China understand the difficulty of using diplomacy to solve commercial matters in BRI and the importance of keeping the settlement of such disputes out of China's diplomatic efforts as far as possible due its impact on the country's relationship with BRI participant States. This scenario will prevent China from refuting the ISDS mechanism which is the best way to provide Chinese investors with delocalised and depoliticised means to resolve their investment disputes in the context of BRI in particular and in the field of foreign investment in general.

\section{$6 \quad$ Concluding Remarks}

China has emerged as a global superpower with phenomenal economic growth and the political will to play an enhanced role in global affairs and the global economy. Consequently, it has become a defender of economic globalisation, a supporter for multilateralism in global economic governance, and a promoter of investment liberalisation. These phenomena have made international investment one of the fields of global governance most likely to be affected by China's rise as a global superpower in general, and its rise as a global investor in particular. Supporting this observation, China provided political leadership to adopt the G2o Guiding Principles for Global Investment Policymaking and joined to work on a multilateral framework on investment facilitation. Furthermore, China's rise has not posed an institutional or ideological threat to existing international system for the protection of foreign investment, thus far. Instead, the country has increasingly espoused substantive and procedural international investment law norms on protection of foreign investments and, this trend is likely to continue, accompanied with possible modifications to promote a balance between private rights of foreign investors and public rights of host States. China's role as a leading capital-exporter in addition to its entrenched position as a main capital-importer makes the balance of public and private rights a matter of utmost concern. However, the increased backlash against economic globalisation and multilateralism in international economic governance in general, and the strong backlash against the existing international system for the protection of foreign investment in particular, will hinder Chinese attempts to convince the global community to adopt a multilateral 
legal framework on the promotion and protection of foreign investment. In addition, Chinese investments are increasingly facing a backlash on the basis of security concerns, lack of reciprocity, neo-colonisation impact, as well as their environmental and social impacts. The increased outward flow Chinese investment mainly in the context of BRI has raised regional as well as global concerns over China's rapid economic expansion and its increased strategic presence, while giving rise to xenophobia in relation to Chinese investments. This scenario would further prevent China from taking a lead role in international investment governance on a multilateral basis. 